\title{
Rules versus authorities
}

\author{
Marianne Johnson ${ }^{1} \mathbb{D}$
}

Received: 23 March 2018 / Accepted: 10 April 2018 / Published online: 3 May 2018

(C) Springer Science+Business Media, LLC, part of Springer Nature 2018

\begin{abstract}
I present a brief history of modern public choice analysis as told through the lens of "rules versus authorities", a dichotomy initially formulated by Henry C. Simons, University of Chicago professor to James M. Buchanan. Framing political decision-making as a choice between rules and authorities allows us to identify two necessary, motivating ideas for the emergence of public choice: (1) Governments are not monolithic, omniscient, social calculating machines, but are instead a collection of individuals with various and possibly competing interests. (2) Rather than empowering bureaucracies, economists and political scientists should devise rules that constrain government experts and protect democratic decision-making. Lurking behind both ideas is the legacy of Simons and his antipathy to expert management of the economy. In that antipathy, Simons makes an important contribution to the intellectual history of public choice and to Buchanan's research program.
\end{abstract}

Keywords James M. Buchanan $\cdot$ Henry C. Simons $\cdot$ Rules $\cdot$ Authorities $\cdot$ History of public choice

JEL Classification $\quad \mathrm{B} 29 \cdot \mathrm{B} 31$

In Europe, the history of public choice is often told as a story of continuity. With the emergence of democratic governments in the late 1800s, economists such as de Marco (1888), Sax (1887), Wicksell (1896), Lindahl (1919) and Pareto (1896-1897, 1906) contemplated rules and strategies for socio-political-economic decision-making and developed criteria to evaluate those decisions. The Scandinavian scholars evidenced a great faith in government's ability to solve economic problems, like the provision of public goods. The Italian

Marianne Johnson

johnsonm@uwosh.edu

1 University of Wisconsin Oshkosh, Oshkosh, USA 
scholars evidenced great distrust of government's ability to do much of anything. These are stories that have lasted through 140 years (Kurrild-Kiltgaard 2018; Peacock 1992).

In the United States, the history of public choice often is told as a story of discontinuity (Buchanan 2007, 2012; Congleton 2012; Coyne 2014; Medema 2005, 2011; Wagner 2004, 2017). In the 1960s, James M. Buchanan and his colleagues and students, including Gordon Tullock, Warren G. Nutter, Richard Wagner, Charles Goetz and Robert D. Tollison, suddenly emerged with ideas of club goods, median voters, government failure and voting with your feet. Buchanan (1987, p. 243) tells us that "armed with Wicksell", he dared to "challenge the still-dominant orthodoxy in public finance and welfare economics". Others identified the study of political decision-making as a "new topic for economists and political scientists" (Tollison 1999, p. 11; see also Buchanan 2012; Congleton 2012). Or take, for example, Buchanan's story of discovering Wicksell's forgotten public finance book buried deep in the stacks of the Chicago library, and suddenly seeing the light.

One of the most exciting intellectual moments of my career was my 1948 discovery of Wicksell's unknown and untranslated dissertation, Finanztheoretische Untersuchungen (1896), buried in the dusty stacks of Chicago's old Harper Library. Only the immediate post-dissertation leisure of an academic novice allowed for the browsing that produced my own dramatic example of learning by serendipity. Wicksell's new principle of justice in taxation gave me a tremendous surge of self-confidence. Wicksell, who was an established figure in the history of economic ideas, challenged the orthodoxy of public finance theory along lines that were congenial with my own developing stream of critical consciousness. (Buchanan 1987, p. 243)

While there is perhaps some reason to doubt the literal truth of this story (Johnson 2014), it is the message of historical disjointedness that is important.

This story of discontinuity, however, belies important ideas that are fundamental to public choice. These ideas evolved from strands of intellectual thought that are autochthonic to American thinking-suspicion of government, suspicion of the motives of experts and intellectuals and a commitment to direct democracy (Hofstadter 1964; Kingdon 1999). The title of this essay is "Rules versus Authorities"; it is borrowed from the title of a paper by Henry C. Simons-University of Chicago professor to Buchanan-writing about monetary policy in the depth of the Great Depression. Framing political decision-making as a choice between rules and authorities allows us to identify two necessary motivating ideas for the development of public choice: (1) Governments are not monolithic, omniscient, social calculating machines, but are instead a collection of individuals with various and possibly competing interests. (2) Rather than empowering bureaucracies, economists and political scientists should devise rules that constrain government experts and protect democratic decision-making. Lurking behind both ideas is the legacy of Simons and his antipathy to expert management of the economy. In that antipathy, Simons makes an important contribution to the intellectual history of public choice and Buchanan's research program. ${ }^{1}$

\footnotetext{
1 The influence of Frank Knight on Buchanan has been well documented (Boettke and Marciano 2015; Buchanan 2007; Buchanan and Musgrave 1999; Coyne 2014; Johnson 2014; Medema 2011). The influence of Simons is underappreciated. There are several reasons why Simons does not feature more prominently. First, Simons represented "public finance orthodoxy for the 1940s" (Buchanan 2007, p. 83). Simons's practical work stressed attention to institutional and technical minutiae, to definitions of terms and to tax law. His contribution to the development of the Haig-Simons definition of income is representative. These topics did not interest Buchanan. Second, Simons's suicide at the end of the spring quarter of 1946 had a dampening effect on the department and on Simons's legacy (Van Horn 2014).
} 


\section{Henry C. Simons and the Chicago school ${ }^{2}$}

Many scholars have argued over the nature and existence of a "Chicago School" of economics (Miller 1962; Stigler 1962; van Overtveldt 2007). Also widely discussed has been the impact of Chicago-School thinking on Buchanan and the development of public choice (Boettke and Marciano 2015; Buchanan 2010; Burns 2016; Johnson 2014). I want to pick up one thread of that discussion as it relates to rules versus authorities.

Throughout the 1930s, the "Old Chicago School" of Jacob Viner, Lloyd Mints, Frank Knight and Henry Simons propagated their own particular approach to monetary policy as a response to the Great Depression, largely eschewing Keynesian [or dirigiste] fiscal policy proscriptions and New Deal spending plans (Burns 2016). ${ }^{3}$ Simons's "Rules Versus Authorities" (1936, pp. 1-2) cast monetary policy as "an intellectual challenge to the liberal faith" and called for a system of "definite rules" rather than the expert "authoritarianism" that had dominated policy making since the establishment of the Federal Reserve Banking System in 1914.

Two years earlier, Simons debuted his course on the Economics of Fiscal Policy at the University of Chicago (EC 361), the same year he published A Positive Program for Laissez Faire (1934a). In both, Simons argued that the role of the state should be to establish the rules of the game and to create institutions that allow for markets to work efficiently. Recommended policies included "the maintenance of competitive conditions in industry; the control of the currency (of the quantity and value of the effective money); the definition of the institution of property (especially with reference to fiscal practices" (Simons 1934a, p. 3). In Personal Income Taxation, Simons made a similar argument:

taxation is only a small element in the structure of the rules and conventions which constitute the framework of our existing economic system; and problems of taxation can be clearly apprehended only as phases of the broad problem of modifying this framework (the rules of the game) in such a manner as to make the system more efficient and more secure. (Simons 1938, p. 2)

In this passage, Simons echoed Knight, who emphasized careful delineation of rules of the game as a remedy for bureaucratic management of the economy (Knight 1946, p. 451).

In the spring of 1946, Buchanan enrolled in Simons's fiscal policy course as part of the sequence for specializing in public finance (Buchanan 2007, p. 70; Johnson 2014). Assigned readings included Simons on debt policy (1944), his rules versus authorities in monetary policy (1936), and his Personal Income Taxation (1938). ${ }^{4}$ At about the same

\footnotetext{
${ }^{2}$ Part of this section is taken from my chapter "Rules Versus Authorites: Buchanan and Simons and Fiscal Policy," forthcoming in James M. Buchanan: A Theorist of Political Economy and Social Philosophy, ed. Richard Wagner. Palgrave Macmillan.

3 Simons's "monetary-fiscal doctrines were very individual, neither traditional nor currently popular, and in one sense radical (extreme or drastic). Their general quality may be gathered even from the 'Laissez Faire' pamphlet just discussed-readers familiar with that will recall its advocacy of the $100 \%$ reserve idea, and a fixed quantity of money. But the present volume offers a much fuller and better presentation of his entire position in this field, in four additional essays: 'Rules versus Authorities in Monetary Policy'-the 'key' article in this group; 'Hansen on Fiscal Policy'-a vigorously hostile, critical review of Professor Hansen's Fiscal Policy and Business Cycles; 'On Debt Policy' - a short paper on the federal debt problem; and 'Debt Policy and Banking Policy"” (Taylor 1948, p. 654).

4 The syllabus and readings for Simons's 1946 fiscal policy course can be found at Irwin Collier's website, Economics in the Rearview Mirror. http://www.irwincollier.com/chicago-henry-simons-last-course-fisca 1-policy-1946/.
} 
time, while he was an undergraduate at the University of Chicago, Tullock took his only formal course in economics from Simons. In it, he too imbibed much of Simons' emphasis on rules and his antipathy for experts. ${ }^{5}$

It is important to remember that during the 1940s, both the economics and the politics of fiscal policy were under heated discussion. According to Alvin Hansen, fiscal policy had become "the central topic" in economics (1945, p. 382). Even in the late 1950s, Buchanan (1958, p. 20) called it "the vital center of attention". Many notable public finance scholars worked at the intersection of fiscal policy and taxation, including Robert Murray Haig, Mabel Newcomer, A. C. Pigou, Paul Samuelson, Carl Shoup and Henry Simons. Much of Richard Musgrave's work falls into this area of overlap, including his classic public finance textbook, which set the task for government as allocation, distribution and stabilization of the economy (Musgrave 1959).

Buchanan's matriculation in Simons's fiscal policy course was coincident with the rollout of the Employment Act of $1946 .{ }^{6}$ The law represented the culmination of a decadeslong shift in economic thinking, enshrining the idea that "...economies were not self-correcting but needed constant government guidance to avoid the twin perils of depression and hyperinflation" (Buchanan and Wagner 1977, p. 13). Nothing could have been further from Simons's position on national economic management, which identified "the real enemies of liberty" as "the naïve advocates of managed economy or national planning" (Simons 1934a, p. 10). Yet, despite Simons's efforts, government management of the economy had been the dominant paradigm for more than 40 years. The Progressives cum Institutionalists who dominated American public finance from the 1880s though the New Deal enshrined the idea of the economist-as-expert and of authorities leveraging scientific knowledge to control and direct economic life. The Second World War vastly expanded the power of the technocrat.

Simons identified two dangers in the fiscal policies of the post-war period. The first was the obvious and well-identified risk of inflation. The second was more insidiousthe danger to democracy arising from governmental policies promulgated by bureaucrats rather than voters or their elected officials. That deficit financing was opaque to voters and manipulated by politicians was particularly problematic for democracy. In the end, Simons argued that

We might have lower morbidity, valuable public assets, a larger tax base, and other good things to show for it. But the magnitude and the rate of increase of internal debt is a measure of political instability and exposure to revolution. We cannot indefinitely and continuously add to the transfer of obligations of our political system without jeopardizing political order (Simons 1942, p. 174).

\footnotetext{
5 Tullock was "influenced by the economics of Henry Simons and Ludwig von Mises, as supplemented by the precursory public choice insights of Joseph Schumpeter and Anthony Downs. Tullock was critical for me both as a means of bolstering my confidence in mounting a challenge to much of the conventional wisdom in political science and as a source of genuinely creative and original ideas" (Buchanan in Buchanan and Musgrave 1999, p. 20). Congleton points out that the phrase "rules of the game" appears most frequently in the chapters of Calculus written by Tullock.

6 With the Employment Act of 1946, the US Federal Government took responsibility for maintaining economic stability through the management of inflation and unemployment. Besides defining macroeconomic policy objectives, the law also established the Council of Economic Advisers and the Joint Economic Committee.
} 
Simons's lessons provided important support for Buchanan, who "had always been antistate, antigovernment, antiestablishment" and who placed a "high residual value on individual liberty" (Buchanan 2007, pp. 5, 72).

The lurking authoritativeness inherent in fiscal policy was a recurring theme in Simons's writings. The danger of the deferral of policy-making to technocrats was that it separated decision-making from both democratic process and public input. Simons claimed

There is imminent danger, however, that actual governmental policies will undermine irreparably the kind of economic and political life which most of us prefer to the possible alternatives. This danger manifests itself mainly...in measures and policies which involve delegation of legislative powers and the setting-up of authorities instead of rules. (Simons 1936, p. 2)

Worried that Harvard's Alvin "Hansen favors large abdication of fiscal powers by Congress in favor of special agencies and their experts", Simons (1942, pp. 179-180) saw too much room for technocrats to "use the powers for consolidating their own position and that of their patron faction".

What [Hansen] proposes, if you will, is collectivism via fiscal policy or fiscal stabilization whose implementation is promiscuous socialization, letting functional minorities do their worst until the socialized sector, grown too large to live parasitically and irresponsibly, itself cries out for protection. (Simons 1942, p. 181)

Instead, "the liberal creed demands the organization of our economic life largely through individual participation in a game with definite rules" (Simons 1936, p. 1). Rather than relying on experts, Simons argued that "only with rules of policy can common national interests be protected against minorities" (Simons 1942, p. 179). Buchanan would turn Simons's idea on its head and argue that only with rules—-such as Wicksellian unanimitycould minorities be protected from majorities in a democratic system. And it is only with rules that the power of bureaucratic authorities (Leviathan) could be constrained.

\section{2 "Rules" in American public choice}

The Calculus of Consent (1962) by Buchanan and Tullock launched public choice (Rowley 2004). The book was "one of the classic works that founded the subdiscipline of public choice" (Tollison 1999, p. 11). It "set off an intellectual revolution in the analysis of politics" (Boettke and Marciano 2015, p. 57). A conference devoted to the book led to the Committee on Non-Market Decision Making, which, in turn, became the Public Choice Society, complete with the journal, Public Choice (Buchanan 2012; see also Boettke and Marciano 2015; Congleton 2012). Congleton (2018) emphasizes the importance of such an ecology — of the interplay of new ideas and of necessary institutional support, including journals, conferences and research centers-for the emergence of a field of research.

If we accept The Calculus as the match that sparked public choice, then it is the logical place to center the intellectual history of the field. A review of the references in The Calculus demonstrates how remarkably contemporary the book was. Nearly all of the references are post-war, harkening to recent developments in game theory and welfare economics. Tullock writes the intellectual history of The Calculus in its second, separately signed appendix, "Theoretical Forerunners." He identifies the "true intellectual roots" in probability, game theory and what he calls the "strict theory of politics". Knight's contributions to rational choice, the nature and meaning of competition, and to the understanding market 
operations also provide important antecedents. His contribution can be summarized: how do people respond to rules? Of dead economists, only Wicksell and Pareto feature prominently, with their contributions of unanimity rule and Pareto efficiency. This was part of a strategic effort to differentiate their product and to emphasize the novelty of the research program (Buchanan 1992, p. 91; see also Johnson 2014).

When considering the advent of the American public choice research program within the framework of rules versus authorities, there is thus little disagreement with the first part. The Calculus was about rules (Buchanan 2012, p. 253). Both Buchanan's first published paper and his Nobel Prize lecture focused on Wicksell's unanimity voting rule (Buchanan 1949, 1987). Buchanan was the first to link Wicksell's unanimity rule with Pareto's rule for optimality, and the first to apply them to social decision-making (Buchanan 1951). ${ }^{7}$ Tullock's (1959) own work emphasized rules in politics. JSTOR returns 493 instances of economics journal articles and book reviews that refer to Buchanan or Tullock and rules. For articles and reviews authored by Buchanan and indexed by JSTOR, 35\% talk about "rules." For Tullock it is 24\%. A search of the archives of the journal Public Choice returns 3122 articles that refer to "rules." Explaining his research program, Buchanan stated that "Wicksell laid out before me a set of ideas that seem to correspond precisely with those that I had already in my head.... If we seek to reform economic policy, we should change the rules under which political agents or representatives act" (Buchanan 1992, pp. 5-6).

\section{3 "Authorities" in public choice}

To bring to the fore the less appreciated half of the rules-versus-authorities dichotomy, we can tell a story about the intellectual history of public choice that emerges from the American classical liberal (libertarian) tradition, beginning with the Founding Fathers and which runs directly through Chicago and Simons. The Calculus set out to translate "some of the philosophical ideas of Thomas Jefferson, James Madison and the other founding fathers" to offer "support for constitutional limits on the exercise of political authority" (Buchanan in Buchanan and Musgrave 1999, p. 21). Long before, Buchanan's doctoral dissertation wrestled with the constitutional problems of fiscal federalism. The federal system "rests upon its limitations to the potential powers of the government over the individual, and in imposing these limitations its preserving and facilitating government by discussion, or the true essence of democracy" (Buchanan 1948, p. 12). Taking a stand against "neo-Hamiltonians" who sought greater centralization of economic and political power with the federal government, Buchanan argued for the maintenance of a federal system, following the

'Nineteenth Century Liberal' tradition that government should be based upon the rule of law, that it should operate in a limited and well-defined area, and that the directions made by government over the economic life of a nation should be general and not particularistic. (Buchanan 1948, p. 18)

In fact, "the general position taken...follows that expressed by the late Professor Henry C. Simons" as laid out in his Positive Program for Laissez Faire (Buchanan 1948, p. 18).

\footnotetext{
7 Of the The Calculus, Tollison (1999, p. 11) wrote "the attack on majority voting procedures and the introduction of relative unanimity rules (à la Knut Wicksell, the famous Swedish economist) has also been a hallmark of Buchanan's work throughout his career. He often speaks of the early influence of Wicksell on his work".
} 
However, it was not just the "excessive aggregation" of government (Boettke and Marciano 2015), but the deferral to expert authority that was fundamentally problematic for Buchanan. Lurking behind Buchanan's analysis of federalism was his deep distrust of centralized government and fear of the loss of democratic process to bureaucratic decisionmaking. Lovejoy (1936) emphasized that our consciously held ideas derive from presuppositions that reside within us about which we likely are unfamiliar. Simons, as well as Knight and Buchanan, had a visceral support for ordinary people over the elites. The difficulty of pigeon-holing Simons's economics_reconciling his support for laissez-faire with his demand for greater antitrust regulation and redistribution of wealth through the income tax - can be resolved when these policies are viewed as a shift of control from Progressivist political authorities to ordinary people. ${ }^{8}$ For Buchanan, his military service under EastCoast elites during the Second World War had been a defining, but not positive experience (Buchanan 1992).

It is perhaps difficult to grasp today the extent to which economists were "basking in the reflected glory of John Maynard Keynes" and the "new role of economists as philosopherkings” (Rowley 2004, p. x). Simons's crusade against Hansen's fiscal policy prescriptions became Buchanan's more philosophical war on Keynes. But it was broader than just fiscal policy-Buchanan extended the battleground to all aspects of socioeconomic decision making. "We are democrats here not autocrats" he reminded his 1963 public finance class (Wagner 2013).

This concern is especially evident in the government failure literature. Bruno Frey notes that "In much of (American) Public Choice a further conclusion has been reached: it is argued that markets are generally superior, and that politics is almost always inferior" (Frey 1992, p. 130). Declaring this an ideological position, Frey argues on the same page that market superiority was not "the real message".

What matters is not the juxtaposition of market failure with political failure but to compare democratic with authoritarian decisions.... The real message of Political Economy [e.g., public choice] thus has to do with the virtues of democracy compared to other political decision-making systems...the dangers of authoritarianism (Frey 1991, pp. 130-131).

People are attracted to the collectivist mentality and willingly cede control over their lives to the state and its experts (Buchanan 2005). The question for Buchanan was how to constrain this tendency and to "chain Leviathan" (Buchanan 1975). In this, Buchanan is very close to Simons's position that "in this simple distinction", between rules and authorities, "lies the choice between democracy and fascism, between freedom and authority" (Simons 1934b, p. 797). Preserving the democratic process was The Reason for Rules (Brennan and Buchanan 1985).

\section{Conclusions}

It is at the intersection of rules and authorities that two important ideas for the development of American public choice become clearly articulated. (1) Governments are not monolithic institutions, nor are they necessarily benevolent. Government is full of people-politicians,

${ }^{8}$ I think Richard Wagner for this insightful comment. 
bureaucrats and office assistants - who have their own interests, and those interests many not be those of the voters. From fiscal policy to public goods, it is fairly ridiculous to assume that "government" knows people's preferences and can translate them into effective economic policies. To assume so when building economic models or outlining theories dooms the models and theories to failure. We see this as early as Buchanan $(1948,1949)$, and though Buchanan attributes the idea to Wicksell, Simons also had an "individualistic" rather than an "organistic" theory of government. How individual-government interactions are modeled says a lot about how economists think and what sorts of policies they are willing to accept; these views often are rooted in deeper precepts. Thus we see a story that positions free markets and rule-making as democratic processes on one side, arrayed against social management and compulsion on the other. (2) What economists and political scientists should do is devise rules to channel voter interests and constrain authorities and bureaucrats. Such rules would be the only effective mechanism to preserve democratic processes.

The rise of the modern, bureaucratic state in the first half of the twentieth century demanded new approaches to the study of political economy. Thus, debate over rules versus authorities goes well beyond theoretical mechanics. Rather, these discussions reveal how the larger context of the post-war period shaped thinking in economics. Interwoven into this story is a related discussion about the nature and meaning of democracy in a state run by experts. The intellectual legacy of Henry C. Simons can be traced from his fight against the technocratic authorities of the New Deal and the post-war Keynesians to Buchanan's approach to public choice. These ideas remain an important part of contemporary public choice, as evidenced by David Levy and Sandra Peart's Escape from Democracy: The Role of Experts and the Public in Economic Policy (2017) and Roger Koppl's Expert Failure (2018). In both, one can hear the echoes of Simons and Buchanan cautioning that the study of "the political economy of experts is to better understand the limits of expertise and to preserve pluralist democracy against managerial bureaucracy” (Salter 2018).

Acknowledgements I would like to thank William Shughart, Richard Wagner, David Siemers, Ross Emmett, and Peter Boettke for helpful comments and suggestions. I would also like to thank my co-panelists at the Public Choice Society conference, Roger Congleton and Peter Kurrild-Klitgaard and the session organizers Georg Vanberg and Edward Lopez.

\section{References}

Boettke, P. J., \& Marciano, A. (2015). The past, present and future of Virginia political economy. Public Choice, 163(1-2), 53-65.

Brennan, G., \& Buchanan, J. M. (1985). The reason of rules. New York, NY: Cambridge University Press.

Buchanan, J. M. (1948). Fiscal equity in a federal state. Ph.D. Dissertation, University of Chicago.

Buchanan, J. M. (1949). The pure theory of government finance, a suggested approach. Journal of Political Economy, 57(6), 496-505.

Buchanan, J. M. (1951). Knut Wicksell on marginal cost pricing. Southern Economic Journal, 18(2), $173-178$.

Buchanan, J. M. (1958). Public principles of public debt: A defense and restatement. Homewood, IL: Richard D. Irwin, Inc.

Buchanan, J. M. (1975). The limits of liberty: Between anarchy and Leviathan. Chicago, IL: University of Chicago Press.

Buchanan, J. M. (1987). The constitution of economic policy. American Economic Review, 77(3), $243-250$.

Buchanan, J. M. (1992). Better than plowing and other personal essays. Chicago, IL: University of Chicago Press.

Buchanan, J. M. (2005). Afraid to be free: Dependency as desideratum. Public Choice, 124(1), 19-31. 
Buchanan, J. M. (2007). Economics from the outside in. College Station, TX: Texas A\&M University Press.

Buchanan, J. M. (2010). Chicago school thinking: Old and new, at the Summer Institute for the History of Economic Thought, Richmond University, June 2. https://www.youtube.com/watch?v=7_atDse06r4. Accessed 10 Feb 2018.

Buchanan, J. M. (2012). Genesis. Public Choice, 152(3-4), 253-255.

Buchanan, J. M., \& Musgrave, R. A. (1999). Public finance and public choice: Two contrasting visions of the state. Cambridge, MA: MIT Press.

Buchanan, J. M., \& Tullock, G. (1999[1962]). The calculus of consent. Ann Arbor, MI: University of Michigan Press.

Buchanan, J. M., \& Wagner, R. E. (1977). Democracy in deficit. New York, NY: Academic Press.

Burns, S. (2016). Old (Chicago) school, new century: The link between knight and Simons' Chicago plan to Buchanan's constitutional money. Constitutional Political Economy, 27(1), 299-318.

Congleton, R. D. (2012). Growing up with the calculus of consent. Public Choice, 152(1-2), 273-278.

Congleton, R. D. (2018). A short overview of the intellectual foundations of public choice, the forest from the trees. Public Choice. Forthcoming.

Coyne, C. (2014). Symposium on James M. Buchanan and classical liberalism. Independent Review, 18(3), $325-330$.

de Marco, A. D. V. (1888). Il carattere teorico dell 'economia finazaris. Rome.

Frey, B. (1992). Commentaries. In A. Peacock (Ed.), Public choice analysis in historical perspective (pp. 129-134). New York, NY: Cambridge University Press.

Hansen, A. (1945). Three methods of expansion through fiscal policy. American Economic Review, 35(3), 382-387.

Hofstadter, R. (1964). The paranoid style in American politics. Harpers Magazine, 229, 77-86.

Johnson, M. (2014). James M. Buchanan, Chicago, and post war public finance. Journal of the History of Economic Thought, 36(4), 479-498.

Johnson, M. (2018). Rules versus authorities: Buchanan and Simons and fiscal policy. In R. Wagner (Ed.), James M. Buchanan: A theorist of political economy and social philosophy. London: Palgrave Macmillan.

Kingdon, J. W. (1999). America the unusual. New York, NY: Worth Publishers.

Knight, F. H. (1946). Review: Freedom under planning. Journal of Political Economy, 54(5), 451-454.

Koppl, R. (2018). Expert failure. New York, NY: Cambridge University Press.

Kurrild-Kiltgaard, P. (2018). Public choice and political science: A view from Europe. Public Choice. Forthcoming.

Levy, D. M., \& Peart, S. J. (2017). Escape from democracy: The role of experts and the public in economic policy. New York, NY: Cambridge University Press.

Lindahl, E. (1919). Die gerechtigkeit besteuerung. Lund.

Lovejoy, A. (1936). The great chain of being. Cambridge, MA: Harvard University Press.

Medema, S. G. (2005). 'Marginalizing' government: From la scienza delle finanze to Wicksell. History of Political Economy, 37(1), 1-25.

Medema, S. G. (2011). Public choice and the notion of creative communities. History of Political Economy, 43(1), 225-246.

Miller, H. L. (1962). On the 'Chicago school of economics'. Journal of Political Economy, 70(1), 64-69.

Musgrave, R. A. (1959). The theory of public finance. New York, NY: McGraw Hill Book Co.

Pareto, V. (1896-1897). Cours d'économie politique. Lausanne: F. Rouge.

Pareto, V. 1971 [1906]. Manual of political economy. New York, NY: A. M. Kelley.

Peacock, A. (1992). Public choice analysis in historical perspective. New York, NY: Cambridge University Press.

Rowley, C. (2004). Introduction. In J. M. Buchanan \& G. Tullock (Eds.), The calculus of consent. Indianapolis, IN: Liberty Fund.

Salter, A. W. (2018). Roger Koppl: Expert failure. Public Choice, 175, 215-217.

Sax, E. (1887). Grundlegung der theoretischen staatswissenschaft. Vienna.

Simons, H. C. (1934a). A positive program for laissez-faire. In Public policy pamphlet No. 15. Chicago, IL: University of Chicago Press.

Simons, H. C. (1934b). Economic reconstruction: The Columbia report. Journal of Political Economy, 42(6), 795-799.

Simons, H. C. (1936). Rules versus authority in monetary policy. Journal of Political Economy, 44(1), 1-30.

Simons, H. C. (1938). Personal income taxation: The definition of income as a problem of fiscal policy. Chicago, IL: University of Chicago Press.

Simons, H. C. (1942). Hansen on fiscal policy. Journal of Political Economy, 50(2), 161-196.

Simons, H. C. (1944). On debt policy. Journal of Political Economy, 52(4), 356-361. 
Stigler, G. (1962). On the 'Chicago school of economics': comment. Journal of Political Economy, 70(1), $70-71$.

Taylor, O. H. (1948). The economics of a 'free' society: Four essays. Quarterly Journal of Economics, 62(5), 641-670.

Tollison, R. D. (1999). Forward. In J. M. Buchanan \& G. Tullock (Eds.), The calculus of consent (pp. 11-12). Ann Arbor, MI: University of Michigan Press.

Tullock, G. (1959). Problems of majority voting. Journal of Political Economy, 67(6), 571-579.

Van Horn, R. (2014). Henry Simons' death. History of Political Economy, 46(3), 525-535.

Van Overtveldt, J. (2007). The Chicago school. Chicago, IL: Agate.

Wagner, R. E. (2004). Public choice as an academic enterprise: Charlottesville, Blacksburg, and Fairfax retrospectively viewed. American Journal of Economics and Sociology, 63(1), 55-74.

Wagner, R. E. (2013). James M. Buchanan and me: Reminiscing about a 50-year association. Journal of Public Finance and Public Choice, 31(1-3), 43-59.

Wagner, R. E. (2017). James M. Buchanan and liberal political economy: A rational reconstruction. Lanham, MD: Lexington Books.

Wicksell, K. (1896). Finanztheoretische untersuchungen. Jena: Gustav Fisher. 